\title{
Götter, Tempel und Kult der Judäo-Aramäer von Elephantine: archäologische und schriftliche Zeugnisse aus dem perserzeit-lichen Ägypten
}

\section{Collin Cornell}

To cite this article: Collin Cornell (2017) Götter, Tempel und Kult der Judäo-Aramäer von Elephantine: archäologische und schriftliche Zeugnisse aus dem perserzeit-lichen Ägypten, Scandinavian Journal of the Old Testament, 31:1, 157-159, DOI: $10.1080 / 09018328.2017 .1325102$

To link to this article: http://dx.doi.org/10.1080/09018328.2017.1325102

\section{Published online: 23 May 2017.}

\section{Submit your article to this journal $\square$}

\section{Џ Article views: 5}

\section{Q View related articles ๘}

\section{View Crossmark data ¿}


Angela Rohrmoser, Götter, Tempel und Kult der Judäo-Aramäer von Elephantine: archäologische und schriftliche Zeugnisse aus dem perserzeitlichen Ägypten (Alter Orient und Altes Testament, 396; Münster: UgaritVerlag, 2014), xvii + 495 pp. EUR 98, bound

This volume is a revised dissertation, completed in 2011 at Tübingen University under the direction of Dr. Herbert Niehr. It is also (in my opinion) the most detailed and comprehensive treatment of the Elephantine cult since Albert Vincent's 1937 work, La Religion des Judéo-Araméens d'Eléphantine. ${ }^{1}$ Like the latter, Rohrmoser provides a global view of the "JudeoAramean" cult at Elephantine, but she exceeds Vincent in her depth of interaction with the island's archaeology and in her re-edition of key texts from its archives. Nor has Rohrmoser's contribution been upstaged by another recent, integrative publication on Judean religion at Elephantine. Gard Granerød's Dimensions of Yahwism in the Persian Period is wideranging and important, but more theologically inclined; oriented more towards Judean beliefs, it lacks Rohrmoser's intensive engagement with the material aspects of their cult, e.g., temple sacrifices and household piety. ${ }^{2}$

Rohrmoser intends her book as Grundlagenforschung - basic or fundamental research, which can then serve as a point of reference for further and more specialized study. She herself suggests that scholarship on monotheism, aniconism, and sacrificial practice in early Judaism may find her book a resource (p. 3). As the title indicates, her undertaking is ambitious: though weighted towards the textual remains, she also draws on archaeological finds to produce a holistic presentation of Judeo-Aramean religion within its Persian-period Egyptian context. Rohrmoser's first chapter introduces the textual data, especially from the Yedoniah archive, and her second chapter overviews the island's historical situation, geography, and archaeological finds. Rohrmoser's third and more expansive chapter describes each Bevölkerungsgruppe relevant to the island: the Persian military administration, the local Egyptians, and the Judeo-Aramean garrison.

These three opening chapters contextualize and prepare for Rohrmoser's more detailed investigations of the Judeo-Aramean cult that follow. They also already contain crucial and contestable claims. Many scholars differentiate strongly between Judeans and Arameans at Elephantine, positing that Judeans lived on the island and worshipped in the YHW temple while Arameans lived onshore and worshipped in the Bethel temple there.

1. Albert Vincent, La religion des Judéo-Araméens d'Éléphantine (Paris: P. Geuthner, 1937). Porten's classic work, Archives from Elephantine (Berkeley: University of California, 1968) deserves honorable mention, but it focuses on the whole of Elephantine society and not the cult specifically.

2. Gard Granerød, Dimensions of Yahwism in the Persian Period: Studies in the Religion and Society of the Judaean Community at Elephantine (BZAW, 488; Berlin: de Gruyter, 2016). His book consists of "sketches of a (descriptive) theology of Persian-period Yahwism" (p. 339). 
Rohrmoser on the other hand hyphenates the two groups, and argues that the Aramaic-speakers of the first cataract did not distinguish precisely between Judeans and Arameans. In her view, "Judeans" also included people of Samarian or north Syrian ancestry, perhaps descendants of refugees from the Assyrian expansion who repatriated to Judah. In terms of their arrival on the island, Rohrmoser cautiously proposes the beginning of the $6^{\text {th }} \mathrm{c}$. or end of the $7^{\text {th }}$ c.: before Cambyses's conquest of Egypt $(525 \mathrm{BCE})$ and possibly before the Deuteronomistic reforms (622 BCE). Rohrmoser calculates that the Judeo-Aramean community consisted of 2500-3000 people - a substantial share of Judeans then living (1.5-10\%).

Rohrmoser's treatment of the cult proper corresponds to her tripartite title: in three very substantial chapters, the heart of the book, she explores the gods, the temple, and the (domestic) cult of the Judeo-Arameans. The triconsonantal form of the Judean god's name (YHW) and theophoric names with the element Bethel both confirm for Rohrmoser the northern, Israelite influence on Judeo-Aramean religion at Elephantine. Alongside capital-B Bethel as a deity name, Rohrmoser also proposes that bethel refers to a betyl or standing stone in the compound divine names Anatbethel and Ashimbethel. Innovatively, Rohrmoser denies that the first element in the similar compound Herembethel indicates a divine name; instead it designates a part of the YHW temple, by which the man Malkiyah swears (TAD B7.2). ${ }^{3}$

In addition to discussing the temple's archaeology and orientation, Rohrmoser's chapter on the temple dedicates a major unit to the question of cult statuary in the YHW temple. Rohrmoser answers the question affirmatively: she detects an oblique reference to plundered statuary in the famous draft petition letter (TAD A4.7/8), and she reads belief in the deity's real, local presence from YHW's title as "the God who dwells in Elephantine." More importantly, Rohrmoser argues that the purpose of the donation list (TAD C3.15) was to restore the statues of the three named deities, YHW, Anatbethel, and Ashimbethel. Rohrmoser also develops a juridical interpretation of the YHW temple's destruction in 410 BCE: the Khnum priests did not instigate a "pogrom" or object to animal sacrifices in the YHW temple. Rather, the pressing issue was a right-of-way dispute, and the local Persian governor decided it was better diplomacy to appease the Egyptians at the expense of the Judeo-Aramean garrison than to risk an Egyptian revolt.

Rohrmoser's chapter on the domestic cult makes a vital contribution: since the original excavators' reports, no scholars of Elephantine Judean religion except Anneler in 1912 and Vincent in 1937 have even acknowl-

3. $\mathrm{TAD}=$ Bezalel Porten and Adena Yardeni, Textbook of Aramaic Documents from Ancient Egypt, 4 vols. (Jerusalem: Hebrew University, Department of the History of the Jewish People, 1986-1999). 
edged (let alone explored) the "forgotten figurines of Elephantine." 4 Discovered in two houses in the town's "Aramaic quarter," these objects include wooden Bes figurines and female terracotta plaques. Rohrmoser tentatively considers the Bes figures under the category teraphim or "household gods," and suggests their function may have been fertility-related or apotropaic. One plaque depicts a naked woman standing between two pillars with a child beside her. Rohrmoser compares it to similar exemplars found in Gaza and Memphis; however, because the proprietorship and dating of the Elephantine objects are so uncertain, Rohrmoser declines the tempting identification of the woman and child with goddesses named in Aramaic texts (like Anatbethel and Ashimbethel).

Rohrmoser's final judgment is that an exact coordination of JudeoAramean religion at Elephantine vis-à-vis the religion of the Old Testament tradition remains impossible: the Judeo-Aramean cult was neither an archaic nor a bastardized form of the latter, but its own, distinctive variant of ancient YHW worship, albeit one unacquainted with the first and second commandments of the Decalogue, or holy scripture in general (p. 374). Götter, Tempel und Kult is an entry that lodges its own judicious and interesting conclusions. It is also built to last as a reference work: Rohrmoser's surveys of prior research are clearly laid out and her chapter summaries are numerated, with main ideas bolded for easy access; her appendices contain helpful charts and chronologies. Few bibliographic oversights are outstanding: one wishes, for instance, that Rohrmoser had engaged several recent articles on Elephantine by Reinhard Kratz, or broadened her comparative repertoire of Egyptian terracotta figurines. But omissions like these are eminently excusable in a work of such already teeming scope. In sum: Granerød says that Porten and Yardeni's Textbook of Aramaic Documents was his "Bible" for studying Elephantine religion, but on this analogy, Rohrmoser's Götter, Tempel und Kult deserves deuterocanonical status - at least. ${ }^{5}$

Collin Cornell

Emory University, Atlanta, GA

collin.cornell@emory.edu

(C) 2017 Collin Cornell

http://dx.doi.org/10.1080/09018328.2017.1325102

4. Hedwig Anneler, Zur Geschichte der Juden von Elephantine (Bern: Max Drechsel, 1912), pp. 84-85; Vincent, La religion des Judéo-Araméens d'Éléphantine, åpp. 677680.

5. Granerød, Dimensions of Yahwism, p. vii. 